\title{
Determinan Perilaku Tes HIV pada Ibu Hamil
}

\section{Determinant of HIV Testing Behavior among Pregnant Women}

\author{
Nanik Setiyawati, Niken Meilani
}

\section{Jurusan Kebidanan Politeknik Kesehatan Kementerian Kesehatan Yogyakarta}

\begin{abstract}
Abstrak
Human immunodeficiency virus (HIV) dan Acquired immune deficiency syndrome (AIDS) merupakan salah satu sorotan dalam pencapaian target Millenium Development Goals (MDGs). Ibu hamil dengan HIV akan berisiko menularkan kepada bayinya. Tes HIV merupakan gerbang pembuka status HIV yang sangat penting dilakukan pada ibu hamil. Penelitian ini bertujuan untuk menentukan determinan perilaku tes HIV pada ibu hamil yaitu tingkat pendidikan, tingkat pengetahuan, persepsi kerentanan diri tertular HIV, sikap, Provider-Initiated Testing and Counselling (PITC) dan ketersediaan sumber informasi (keluarga dan kader kesehatan). Jenis penelitian adalah potong lintang dengan metode survei. Penelitian ini dilakukan di Puskesmas Mantrijeron dan Puskesmas Sleman yang telah memiliki sarana pemeriksaan tes HIV dan telah menjalankan program Pencegahan Penularan dari lbu ke Anak (PPIA). Subjek penelitian adalah ibu hamil yang berkunjung ke puskesmas tersebut pada bulan Agustus sampai dengan Oktober 2014 yang berjumlah 54 orang. Pengumpulan data menggunakan kuesioner. Analisis yang digunakan univariat, bivariat, dan multivariat. Hasil penelitian menunjukkan tidak ada hubungan tingkat pendidikan, tingkat pengetahuan tentang HIV dan AIDS, persepsi kerentanan diri dan sikap ibu. Ada hubungan antara PITC, ketersediaan sumber informasi tentang HIV dan AIDS dari keluarga dan kader kesehatan dengan perilaku tes HIV pada ibu hamil. PITC merupakan variabel yang paling berpengaruh terhadap perilaku tes HIV pada ibu hamil.

Kata kunci: Provider-Initiated Testing and Counselling, ketersediaan informasi, tes HIV ibu hamil
\end{abstract}

\footnotetext{
Abstract

Human immunodeficiency virus (HIV) and Acquired immune deficiency syndrome (AIDS) is one of highlighted issues in accomplishing Millenium Development Goals (MDGs) target. Pregnant women with HIV will transmit the virus to their babies. HIV testing is such an opening gate of HIV status that is very important to be conducted on pregnant women. This study
}

aimed to determine the determinant of HIV testing behaviour among pregnant women including education level, knowledge level, perception of selfvulnerability to be HIV-infected, attitudes, Provider-Initiated Testing and Counseling (PITC) and availability of information (family and health workers). This study was cross sectional using a survey method. This study was conducted in Mantrijeron and Sleman Primary Health Care that had HIV testing facilities and executed prevention of mother to child transmission program. The subjects of this study were pregnant women visiting such primary health care on August up to October 2014, as much as 54 people. Data collecting used questionnaire. Analysed used were univariate, biviariate, and multivariate. The results showed no relation between educational level, knowledge level about HIV and AIDS, perception of self-vulnerability and attitudes of women.There was a relation between PITC, information source availability about HIV and AIDS from the family and health workers with HIV testing behaviour among pregnant women. PITC is the most influencing variable toward HIV testing behaviour among pregnant women.

Keywords: Provider-Initiated Testing and Counselling (PITC), availability of information, HIV testing on pregnant women

\section{Pendahuluan}

Kasus human immunodeficiency virus (HIV) dan acquired Immune Deficiency Syndrome (AIDS) merupakan masalah utama dalam pencapaian Millenium Development Goals (MDGs) pada tujuan keenam. Hal ini disebabkan karena penyakit ini dapat membawa dampak yang menghancurkan, bukan hanya terhadap kesehatan masyarakat, namun juga negara. ${ }^{1}$ HIV menyerang sel-sel darah putih yang merupakan bagian dari

Korespondensi: Nanik Setiyawati, Jurusan Kebidanan Poltekkes Kemenkes Yogyakarta, Jl. Mangkuyudan MJ III/304 Yogyakarta 55143, No.Telp: 0274374331, e-mail: nanikyogya@gmail.com 
sistem kekebalan tubuh terhadap penyakit. Akibatnya, seseorang yang terinfeksi virus ini mengalami penurunan kekebalan alami tubuh. Kumpulan gejala penyakit yang ditimbulkan akibat rusaknya sistem kekebalan tubuh disebut AIDS. ${ }^{2}$

Berdasarkan data Kementerian Kesehatan Republik Indonesia pada bulan Desember tahun 2013 akumulasi kasus HIV di Indonesia dari bulan April 1987 sampai dengan Desember 2013 tercatat 127.416 kasus dan 29.037 terdeteksi pada tahun 2013. Dari jumlah akumulasi tersebut, mayoritas ada pada rentang usia 20 - 29 tahun, yaitu sebesar 17.892. Kasus HIV baru setiap tahun meningkat seperti tahun 2012 ditemukan 21.511 kasus, sedangkan tahun 2013 meningkat menjadi 29.037.3

Prevalensi tertinggi kejadian AIDS ada di Papua, yang diikuti oleh Bali, DKI Jakarta, Kalimantan Barat, Sulawesi Utara, Maluku, dan pada peringkat ketujuh diduduki oleh Daerah Istimewa Yogyakarta (DIY). DIY sebagai salah satu provinsi yang memiliki prevalensi HIV cukup tinggi dibandingkan daerah lainnya dengan jumlah prevalensi kejadian AIDS sebesar 26,49\%. ${ }^{3}$

Penemuan kasus HIV positif pada akhir tahun 2013 di DIY menurut komisi penanggulangan AIDS Yogyakarta diketahui kasus tertinggi di DIY adalah Kota Yogyakarta 677 kasus, diikuti Kabupaten Sleman dengan jumlah 544 kasus, kemudian Kabupaten Bantul dengan kasus berjumlah 473, disusul Kabupaten Gunungkidul dengan jumlah kasus 119, dan terakhir Kabupaten Kulon Progo dengan jumlah kasus 114. Berdasarkan data di atas, tampak untuk Kota Yogyakarta menduduki peringkat pertama kasus HIV dan AIDS kemudian kabupaten Sleman, Bantul, Gunung Kidul dan Kulon Progo.

Jumlah perempuan yang terinfeksi HIV dari tahun ke tahun semakin meningkat, seiring dengan meningkatnya jumlah laki-laki yang melakukan hubungan seksual tidak aman yang akan menularkan HIV pada pasangan seksualnya. ${ }^{4}$ Pada ibu hamil, HIV bukan hanya ancaman bagi keselamatan jiwa ibu, tetapi juga merupakan ancaman bagi anak yang dikandungnya karena penularan yang terjadi dari ibu ke bayinya. Lebih dari 90\% kasus anak HIV mendapatkan infeksi dengan cara penularan dari ibu ke anak (mother-to-child transmission / MTCT). ${ }^{4}$

Kementerian Kesehatan Republik Indonesia memperkirakan jika di Indonesia setiap tahun terdapat 9.000 ibu hamil dengan HIV positif melahirkan bayi, berarti akan lahir sekitar 3.000 bayi dengan HIV positif tiap tahun. Ini akan terjadi jika tidak terdapat intervensi. Risiko penularan HIV dari ibu ke bayi berkisar 24 - 25\%. Namun, risiko ini dapat diturunkan menjadi dengan tindakan intervensi bagi ibu hamil HIV positif, yaitu layanan penyuluhan dan tes HIV, pemberian obat antiretroviral, persalinan sectio caesaria, serta pemberian susu formula untuk bayi. 3,5
Menurut laporan Joint United Nations Programme on HIV-AIDS (UNAIDS) tahun 2009, terdapat kemajuan signifikan dalam upaya pencegahan penularan HIV dari ibu ke anak, yaitu dengan tes HIV. Salah satu sebab meningkatnya cakupan tes HIV pada ibu hamil adalah meningkatnya tes HIV atas inisiatif pemberi layanan kesehatan dan penyuluhan di layanan / klinik antenatal dan persalinan, dan layanan kesehatan lainnya. ${ }^{4}$

Tes HIV merupakan pintu gerbang utama atau critical gateway dalam rangkaian penanganan kasus HIV. Diketahuinya status HIV seseorang, akan ada pemberdayaan, baik dari diri maupun pasangan dalam pencegahan penularan HIV dan AIDS. Pada ibu hamil, diketahuinya status HIV seseorang akan dapat segera mungkin dilakukan program pencegahan penularan dari ibu ke anak (PPIA). Penyuluhan dan tes HIV juga dinyatakan sebagai titik awal dalam kunci penanganan HIV menurut UNAIDS dalam strategi yang dicapai menuju 'getting to zero'. ${ }^{6}$

Puskesmas sebagai salah satu unit pelayanan dasar menjadi bagian penting dalam beberapa program kesehatan termasuk PPIA. Namun, belum seluruh puskesmas di Yogyakarta menjalankan program PPIA dan memiliki sarana atau fasilitas tes HIV. Puskesmas Sleman merupakan puskesmas percontohan di kabupaten yang telah gencar melakukan program pencegahan HIV sejak tahun 2011 dan telah dijadikan rujukan untuk program PPIA di wilayah Yogyakarta. Demikian pula Puskesmas Mantrijeron sebagai salah satu puskesmas rujukan program penanganan HIV dan AIDS di Kota Yogyakarta.

Tujuan dari penelitian ini adalah untuk menetukan determinan perilaku ibu hamil dalam melakukan tes HIV dengan menggunakan kerangka teori dari Lawrence W Green. ${ }^{7}$ Faktor predisposisi dalam penelitian ini yang diteliti adalah tingkat pengetahuan, tingkat pendidikan, persepsi dan sikap. Faktor penguat adalah provider initiated testing and counselling (PITC) dan faktor pemungkinnya adalah ketersediaan sumber informasi tentang HIV dan AIDS yang bersumber dari keluarga dan kader kesehatan.

\section{Metode}

Penelitian ini adalah penelitian kuantitatif analitik korelasional dengan menggunakan metode survei. Penelitian ini dilaksanakan di Puskesmas Mantrijeron, Kota Yogyakarta dan Puskesmas Sleman, Kabupaten Sleman pada bulan Agustus sampai dengan Oktober 2014. Populasi target dalam penelitian ini adalah semua ibu hamil. Populasi terjangkau dalam penelitian ini adalah ibu hamil yang datang berkunjung ke Puskesmas Mantrijeron dan Puskesmas Sleman. Kriteria inklusi dalam penelitian ini adalah ibu yang bisa membaca dan menulis serta ibu yang bersedia menjadi responden. Sedangkan kriteria eksklusi dalam penelitian ini adalah 
ibu hamil bukan penduduk wilayah kerja puskesmas tersebut. Perhitungan besar sampel menggunakan rumus penghitungan proporsi menurut Isaac dan Michael dengan jumlah populasi ibu hamil di puskesmas tersebut pada bulan sebelumnya sebanyak 81 . Besar sampel minimal dalam penelitian ini adalah $51 \mathrm{ibu}$ hamil, dan dalam penelitian ini sampel yang digunakan sejumlah $54 \mathrm{ibu}$ hamil. Teknik sampling adalah menggunakan purposive sampling dimana mengambil satu puskesmas di wilayah Kota Yogyakarta dan Kabupaten Sleman dengan kasus HIV terbanyak di DIY. Puskesmas yang digunakan sebagai tempat penelitian adalah Puskesmas Mantrijeron dan Puskesmas Sleman. Sebagaimana kedua puskesmas tersebut merupakan puskesmas percontohan dan rujukan penanganan HIV dan AIDS, telah melaksanakan program PPIA, dan memiliki sarana serta fasilitas tes HIV.

Variabel bebas penelitian ini adalah tingkat pendidikan, tingkat pengetahuan tentang HIV dan AIDS, persepsi kerentanan diri tertular HIV, sikap terhadap tes HIV, inisiatif pemberi layanan kesehatan untuk melakukan tes HIV, dan ketersediaan sumber informasi (keluarga, lingkungan, dan kader kesehatan). Variabel terikat penelitian ini perilaku tes HIV yaitu apakah ibu hamil pernah melakukan tes HIV selama hamil sampai dengan saat penelitian berlangsung.

Alat pengumpulan data dalam penelitian ini adalah menggunakan kuesioner yang sebelumnya telah dilakukan uji validitas dan reliabilitas di Puskesmas Melati II, Kabupaten Sleman dan Puskesmas Tegalrejo, Kota Yogyakarta. Proses pengambilan data dilakukan setiap hari kunjungan pelayanan antenatal di masing-masing puskesmas dan ibu hamil diberi penjelasan tentang prosedur penelitian dan diminta mengisi kuesioner dengan waktu selama 60 menit. Analisis yang dilakukan adalah analisis univariat, analisis bivariat menggunakan uji kai kuadrat dan multivariat dengan menggunakan uji regresi logistik.

\section{Hasil}

Karakteristik responden yang diteliti adalah usia, nomor urut kehamilan, dan tingkat pendidikan. Dapat dilihat pada Tabel 1 berdasarkan usia dalam penelitian ini bahwa kelompok usia responden dibedakan berdasar rerata yaitu $\geq 29$ tahun sebesar 51,9\% dan $<29$ tahun sebesar $49,1 \%$. Sedangkan nomor urut kehamilan dalam penelitian ini mayoritas adalah multigravida, yaitu sebesar $63 \%$, sedangkan yang hamil pertama kali atau primigravida sebesar $37 \%$. Untuk perilaku ibu hamil dalam melakukan tes HIV, diketahui bahwa mayoritas ibu belum melakukan tes HIV. Baru 37\% ibu hamil yang melakukan tes HIV, padahal diketahui bahwa dua puskesmas ini merupakan puskesmas yang telah menerapkan program pencegahan penularan HIV dan AIDS dari ibu ke anak dan memiliki sarana / fasilitas tes HIV dengan menggunakan rapid test (Tabel 1).

Dalam penelitian ini, diketahui bahwa terdapat banyak faktor yang secara teori merupakan pembentuk perilaku, akan tetapi tidak semua faktor tersebut membentuk perilaku tes HIV pada ibu hamil. Dapat dilihat dalam Tabel 2 bahwa terdapat beberapa variabel yang tidak berhubungan dengan perilaku ibu, diantaranya tingkat pendidikan yang sebagian besar responden berpendidikan $\geq 12$ tahun, yaitu sebesar $81,4 \%$ tetapi secara statistik, tingkat pendidikan tidak berhubungan dengan perilaku tes HIV dengan nilai $p=0,291$. Demikian pula untuk tingkat pengetahuan mayoritas responden berpengetahuan baik, yaitu sebesar 54\%. Akan tetapi, variabel ini juga tidak berhubungan dengan perilaku

Tabel 1. Analisis Univariat Determinan Perilaku Tes HIV pada Ibu Hamil

\begin{tabular}{llll}
\hline Karakteristik & Kategori & n & $\%$ \\
\hline Usia & $\geq 29$ tahun & 28 & 51,9 \\
Gravida & $<29$ tahun & 26 & 48,1 \\
& primigravida & 20 & 37 \\
Tingkat pendidikan & multigravida & 34 & 63 \\
& $\geq 12$ tahun & 44 & 81 \\
Tingkat pengetahuan & $<12$ tahun & 10 & 19 \\
& Baik & 29 & 54 \\
Persepsi kerentanan diri & Kurang & 25 & 46 \\
& Berisiko & 50 & 92,6 \\
Sikap ibu terhadap tes HIV & Tidak berisiko & 4 & 7,4 \\
Inisiatif pemberi layanan kesehatan & Mendukung & 27 & 50 \\
untuk melakukan tes HIV & Kurang mendukung & 27 & 50 \\
Ketersediaan sumber Informasi dari keluarga & Ya & 28 & 51,9 \\
& Tidak & 26 & 48,1 \\
Ketersediaan sumber informasi dari kader & Tidak & 31 & 57,4 \\
& Ya & 23 & 42,6 \\
Tes HIV & Tidak & 43 & 79,6 \\
& Ya & 11 & 20,4 \\
& Tidak & 20 & 37 \\
& & 34 & 63 \\
\hline
\end{tabular}


Tabel 2. Analisis Bivariat Determinan Perilaku Tes HIV pada Ibu Hamil

\begin{tabular}{|c|c|c|c|c|c|c|c|c|}
\hline \multirow{3}{*}{ Variabel } & \multirow{3}{*}{ Kategori } & \multicolumn{6}{|c|}{ Perilaku Tes HIV } & \multirow{3}{*}{ Nilai $p$} \\
\hline & & \multicolumn{2}{|c|}{ Ya } & \multicolumn{2}{|c|}{ Tidak } & \multicolumn{2}{|c|}{ Jumlah } & \\
\hline & & $\mathbf{n}$ & $\%$ & $\mathbf{n}$ & $\%$ & $\mathbf{n}$ & $\%$ & \\
\hline \multirow[t]{2}{*}{ Tingkat pendidikan } & $\geq 12$ tahun & 18 & 40,9 & 26 & 59,1 & 44 & 100 & 0,291 \\
\hline & $<12$ tahun & 2 & 20 & 8 & 80 & 10 & 100 & \\
\hline \multirow[t]{2}{*}{ Tingkat pengetahuan } & Baik & 9 & 31 & 20 & 69 & 29 & 100 & 0,325 \\
\hline & Kurang & 11 & 44 & 14 & 56 & 25 & 100 & \\
\hline \multirow[t]{2}{*}{ Persepsi kerentanan diri } & Berisiko & 2 & 50 & 2 & 50 & 4 & 100 & 0,622 \\
\hline & Tidak berisiko & 18 & 36 & 32 & 64 & 50 & 100 & \\
\hline \multirow[t]{2}{*}{ Sikap ibu terhadap tes HIV } & Mendukung & 12 & 44,4 & 15 & 55,6 & 27 & 100 & 0,260 \\
\hline & Kurang mendukung & 8 & 29,6 & 19 & 70,4 & 27 & 100 & \\
\hline \multirow[t]{2}{*}{ PITC } & $\mathrm{Ya}$ & 18 & 64,3 & 10 & 35,7 & 28 & 100 & 0,000 \\
\hline & Tidak & 2 & 7,7 & 24 & 92,3 & 26 & 100 & \\
\hline \multirow[t]{2}{*}{ Ketersediaan sumber informasi dari keluarga } & Ya & 15 & 48,4 & 16 & 51,6 & 31 & 100 & 0,045 \\
\hline & Tidak & 5 & 21,7 & 18 & 78,3 & 23 & 100 & \\
\hline \multirow[t]{2}{*}{ Ketersediaan sumber informasi dari kader kesehatan } & Ya & 19 & 44,2 & 24 & 55,8 & 43 & 100 & 0,039 \\
\hline & Tidak & 1 & 9,1 & 10 & 90,9 & 11 & 100 & \\
\hline
\end{tabular}

PITC : Provider Initiated Testing and Counseling

dalam melakukan tes HIV. Variabel lain yang tidak berhubungan adalah sikap ibu terhadap tes HIV (nilai p $=0,260)$ dan persepsi ibu tentang kerentanan diri tertular HIV (nilai $\mathrm{p}=0,622$ ). Mayoritas ibu menyatakan dirinya tidak berisiko tertular HIV, yaitu sebesar 92,6\%. Adapun variabel yang secara statistik berhubungan dengan perilaku tes HIV pada Tabel 2 adalah ketersediaan sumber informasi dari keluarga (nilai $p=0,045$ ), dari kader kesehatan (nilai $\mathrm{p}=0,039$ ) dan inisiatif pemberi layanan kesehatan untuk melakukan tes HIV dengan nilai $\mathrm{p}=0,000$.

Semua variabel yang berhubungan pada analisis bivariat (Tabel 3) dianalisis multivariat. Hasil analisis multivariat pada Tabel 4 menunjukkan bahwa PITC merupakan variabel yang paling berpengaruh dalam perilaku tes HIV pada ibu hamil, yaitu dengan nilai exp (B) sebesar 21,6 . Hal ini berarti bahwa ibu hamil yang mendapatkan inisiasi dari pemberi layanan kesehatan untuk melakukan tes HIV berpeluang untuk melakukan tes HIV sebesar 21,6 kali lebih besar dibandingkan dengan ibu hamil yang tidak mendapatkan inisiasi dari pemberi layanan kesehatan.

\section{Pembahasan}

Penelitian ini berfokus pada penilaian hubungan faktor determinan yang berkontribusi pada perilaku ibu hamil dalam tes HIV. Menurut teori perilaku Lawrence W Green, terdapat beberapa antesenden seseorang dalam berperilaku, diantaranya adalah predisposing faktor yang dalam penelitian ini terdiri dari karakteristik ibu (usia, gravida), tingkat pengetahuan, persepsi dan sikap, reinforcing factor yaitu inisiatif pemberi layanan kesehatan, dan enabling factor yaitu ketersediaan sumber informasi mengenai HIV/AIDS.
Tabel 3. Analisis Multivariat Determinan Perilaku Tes HIV pada Ibu Hamil

\begin{tabular}{lc}
\hline Variabel & Nilai $\mathbf{p}$ \\
\hline PITC & 0,000 \\
Ketersediaan sumber informasi dari keluarga & 0,045 \\
Ketersediaan sumber informasi dari kader kesehatan & 0,039 \\
\hline
\end{tabular}

Tabel 4. Model Akhir Determinan Perilaku Tes HIV pada Ibu Hamil

\begin{tabular}{lcccccc}
\hline Variabel & B & Wald & Df & Nilai p & Exp (B) & 95\% CI \\
\hline PITC & 3,073 & 13,542 & 1 & 0,000 & 21,600 & $4,204-110,970$ \\
\hline
\end{tabular}

Puskesmas yang diambil sebagai tempat penelitian merupakan puskesmas yang telah menjalankan program pencegahan penularan HIV dan AIDS dari ibu ke anak, atau dikenal juga dengan istilah PMTCT atau PPIA dan memiliki sarana tes HIV, akan tetapi hasil penelitian ini menunjukkan hanya $37 \%$ ibu hamil yang telah diketahui status HIV-nya melalui tes HIV. Persentase ibu hamil yang masih sedikit ini juga hampir sama dengan penelitian Karamagi bahwa prevalensi tes HIV pada ibu hamil di Uganda hanya sebesar 10\%.8 Padahal tes HIV merupakan hal yang sangat krusial, seperti pernyataan yang terdapat dalam penelitian Hensen dkk dan Pottie dkk yang menyatakan bahwa tes dan penyuluhan HIV merupakan pintu gerbang utama atau sebagai kunci pembuka program penanganan HIV. Leon dkk juga menyatakan bahwa tes HIV merupakan langkah terpenting dalam program pencegahan dan penanganan HIV.6,9,10 Dengan belum banyaknya ibu hamil yang diketahui status HIVnya, PPIA tentunya tidak akan dapat berjalan dengan baik.

Hasil penelitian ini menyatakan bahwa mayoritas ibu hamil telah memiliki pengetahuan yang baik dan berpendidikan $\geq 12$ tahun tetap tidak saja menjadikan kesediaan 
responden untuk melakukan tes HIV. Secara umum, pengetahuan ibu tentang HIV telah baik, namun tedapat beberapa hal krusial yang masih tidak diketahui oleh responden. Hal ini dapat dilihat melalui jawaban responden dalam kuesioner, diantaranya sebanyak $66 \%$ responden tidak mengetahui bahwa HIV dapat ditularkan melalui proses persalinan, sebesar $65 \%$ responden juga tidak mengetahui bahwa seorang ibu hamil yang terinfeksi virus HIV sebaiknya melahirkan secara operasi. Sebesar 90,7\% beranggapan bahwa status HIV pada ibu hamil telah cukup untuk diketahui dengan pemeriksaan kehamilan saja. Tingkat pendidikan dan pengetahuan merupakan salah satu faktor predisposisi untuk berperilaku menurut teori L. Green. Idealnya, semakin tinggi pendidikan dan pengetahuan seseorang akan berperilaku positif, namun dalam penelitian ini pengetahuan tidak berhubungan dengan perilaku tes HIV dimungkinkan ada informasi yang kurang tepat di atas.

Penyebab lain yang diduga menjadi penyebab masih sedikitnya ibu hamil yang melakukan tes HIV adalah mayoritas ibu memiliki persepsi bahwa dirinya tidak berisiko tertular HIV. Tidak dapat dipungkiri bahwa stigma HIV masih sangat kental di masyarakat yang menjadikan ibu hamil merasa takut mengetahui bahwa dirinya terinfeksi HIV atau tidak. Senada dengan hasil penelitian ini adalah penelitian yang dilakukan oleh Rogers, et al., ${ }^{11}$ di India yang menyatakan bahwa sebanyak $85 \%$ ibu hamil menyatakan keberatan melakukan tes HIV secara sukarela karena ketakutan akan terbukanya status HIV-nya, juga ketakutan terhadap reaksi dari suami, orangtua, dan masyarakat.

Barier sosial dan budaya yang paling berpengaruh dari seorang ibu hamil untuk menerima atau menolak tes HIV. Rogers, et al., ${ }^{11}$ menyatakan bahwa perlu melibatkan suami, inovasi budaya yang berorientasi pada upaya penghapusan stigma dan diskriminasi dimungkinkan dapat menjadi upaya kesediaan para ibu hamil melakukan tes HIV. Demikian pula yang dinyatakan Paoli, et al.,12 bahwa stigma berpengaruh terhadap kesediaan seseorang untuk melakukan tes HIV. Perlunya peran keluarga dan masyarakat untuk melakukan hal ini. Penelitian lain oleh Smolak dan Bassel menunjukkan bahwa stigma negatif dari masyarakat tentang HIV dan AIDS berpengaruh terhadap kesediaan melakukan tes HIV, sedangkan stigma yang berasal dari diri sendiri dan keluarga berpengaruh terhadap penolakan tes HIV. Senada dengan hal tersebut, mengenai sikap responden yang sebagian besar menyatakan bahwa ketidaksediaan tes HIV karena seseorang merasa sehat dan menganggap bahwa infeksi HIV merupakan penyakit yang tidak akan sembuh. Persepsi yang ada pada dirinya sendiri yang merupakan pandangan negatif (stigma) ini menjadi salah satu penyebab ibu tidak bersedia melakukan tes HIV. ${ }^{13}$

Faktor persepsi terhadap kerentanan diri tertular HIV responden memiliki persepsi bahwa dirinya tidak berisiko tertular HIV (92,6\%). Persepsi merasa tidak berisiko tertular HIV membuat responden berada pada zona aman untuk tidak melakukan tes HIV. Persepsi tidak berisiko ini dapat terjadi karena sebagian besar respoden adalah sebagai ibu rumah tangga sehingga mereka menganggap bahwa perilaku meraka jauh dari perilaku berisiko tertular HIV dan AIDS. Berbeda dengan penelitian Rogers, et al., ${ }^{11}$ yang menyatakan $74 \%$ berisiko dirinya tertular HIV dan AIDS. Salah satu kemungkinan adalah budaya ketimuran yang menjadikan para responden merasa malu atau tidak trerbuka untuk menilai kemungkinan dirinya tertular HIV dan AIDS. Diketahui tingkat pengetahuan yang tinggi, tetapi diiringi oleh persepsi dan keyakinan diri bahwa dirinya tidak berisiko, maka pengetahuan menjadi tidak ada artinya. Kembali bahwa keyakinan ini tentunya terbentuk sekian waktu, dan harus dilakukan upaya yang serius dengan melibatkan keluarga, khususnya suami dan lingkungan, agar ibu hamil meyakini bahwa tes HIV sangat diperlukan dalam hal membuka status kesehatan seorang ibu hamil yang kemudian akan berpengaruh pada kesehatan dan masa depan bayi yang dilahirkan. ${ }^{11}$

Penelitian ini menunjukkan bahwa determinan pembentuk perilaku yang secara statistik berhubungan adalah ketersediaan informasi mengenai HIV dari keluarga dan kader kesehatan. Sumber informasi dari keluarga juga menunjukkan hasil yang signifikan. Sumber informasi ini di antaranya dari pasangan. Hal ini dapat dipengaruhi oleh kebudayaan di Jawa yaitu patrilineal dimana perempuan bukan sebagai pengambil keputusan dalam keluarga maupun dirinya. Lebih lanjut disampaikan dalam penelitian Paoli, et al.,12 bahwa ibu yang bersedia melakukan upaya pencegahan penularan infeksi dari ibu ke anak diperlukan adanya kesediaan pendampingan dari pasangan. Penelitian oleh Baiden, et al., ${ }^{14}$ di Ghana menyatakan bahwa determinan yang memengaruhi persepsi ibu untuk melakukan tes HIV adalah peran pasangan lebih besar daripada manfaat dari tes HIV.

Inisiasi dari pemberi layanan kesehatan atau PITC di puskesmas secara statistik menunjukkan adanya hubungan dengan perilaku ibu hamil dalam tes HIV. Bahkan PITC di puskesmas merupakan satu-satunya faktor yang berpengaruh terhadap tes HIV. Kesadaran masyarakat, khususnya ibu hamil untuk melakukan tes HIV secara sukarela masih sangat rendah. Kemungkinan masih tingginya stigma tentang HIV yang membuat seseorang takut untuk melakukan pemeriksaan tes HIV sehingga membutuhkan inisiasi dari petugas. Hal senada berdasarkan penelitian yang dilakukan oleh Ivers, et al., ${ }^{15}$ yang menyatakan bahwa $85 \%$ pasien melakukan tes HIV setelah dilakukan inisiasi oleh petugas. Demikian pula penelitian oleh Hensen, et al., ${ }^{9}$ bahwa inisiatif pem- 
beri layanan untuk melakukan penyuluhan dan tes terbukti memberikan peningkatan pengetahuan bagi ibu hamil pada pra penyuluhan dan post penyuluhan dan meningkatkan jumlah ibu hamil yang melakukan tes HIV. Meskipun demikian, tes HIV yang didasarkan atas kesadaran sendiri tentunya lebih baik, seperti dikutip dari penelitian Salari yang menyatakan tes HIV pada semua ibu hamil sangat penting terutama pada kunjungan pertama pemeriksaan antenatal. Tenaga kesehatan harus memberikan penjelasan yang cukup agar ibu hamil menjalani tes atas kesadaran sendiri. ${ }^{9-16}$ Hardisman, ${ }^{17}$ menyatakan bahwa pentingnya peran pelayanan kesehatan dalam penanganan HIV dan AIDS diperlukan adanya edukasi dan promosi kesehatan yang dalam penelitian ini dapat difasilitasi oleh konseling kemudian dilanjutkan tes HIV. Jika ternyata terbukti positif HIV, maka diperlukan pengobatan yang tepat.

\section{Kesimpulan}

Tingkat pengetahuan ibu hamil tentang HIV dan AIDS adalah kategori baik. Persepsi ibu hamil tentang kerentanan diri memiliki persepsi tidak berisiko tertular HIV dan AIDS, atau dengan kata lain, mereka punya keyakinan bahwa mereka sehat dan tidak akan tertular HIV dan AIDS. Sikap ibu hamil tentang tes HIV seimbang antara yang mendukung dan tidak mendukung tes HIV. Tidak terdapat hubungan tingkat pendidikan, tingkat pengetahuan, persepsi, sikap, ketersediaan informasi dari lingkungan dan organisasi kemasyarakatan. Terdapat hubungan antara inisiasi pemberi layanan, ketersediaan informasi dari keluarga dan kader kesehatan. Inisiasi pemberi layanan untuk melakukan tes HIV merupakan faktor yang paling berpengaruh terhadap perilaku tes HIV pada ibu hamil.

\section{Saran}

Diperlukan pendampingan oleh tenaga kesehatan kepada ibu hamil, khususnya meluruskan persepsi yang masih keliru mengenai HIV dan AIDS maupun pelaksanaan tes HIV. Kemudian diperlukan pelaksanaan inisiasi pemberi layanan kesehatan untuk melakukan tes HIV pada semua ibu hamil, mengingat bahwa terbukanya status HIV seseorang melalui tes HIV merupakan pintu gerbang utama dalam program pencegahan dan penanganan HIV, khususnya pintu penularan dari ibu ke janin atau anak yang dilahirkannya.

\section{Daftar Pustaka}

1. Peter S. Millenium Development Goals. Jakarta: UNDP; 2008 [cited 2014 Aug 4]. Available from:http://www.id.undp.org/content/dam/indonesia/docs/MDG/pdf.
2. Nasronudin. HIV\&AIDS pendekatan biologi molekuler, klinis dan sosial. Surabaya: Airlangga University Press; 2007.

3. Komisi Penanggulangan AIDS Nasional. Kebijakan PMTCT di Indonesia. Jakarta: KPAN; 2008.

4. Kemterian Kesehatan Republik Indonesia. Rencana aksi nasional pencegahan penularan HIV dari ibu ke anak (PPIA) Indonesia 2013-2017. Jakarta: Kementerian Kesehatan Republik Indonesia; 2013.

5. Wistiani. Prevention mother to child transmission HIV (PMTCT) [tesis]. Semarang: Fakultas Kedokteran Universitas Dipenogoro; 2008.

6. Pottie K, Medu O, Weich V, Dahai GV, Tyndall M, Rader T, et al. Effect of rapid HIV testing on HIV incidence and services in population at high risk for HIV exposure: an equity-focused systematic review. BMJ Open. 2014; 4:e006859: 1-13.

7. Green LW. Health promotion planning an educational and environmental approach. Mountain View Toronto - London: Mayfield Publ Co; 2000.

8. Karamagi CAS, Tumwine JK, Tylleskar T, Heggenhougen K. Antenatal HIV testing in rural Eastern Uganda in 2003. BioMed Central. 2006; 6 (6): $1-10$.

9. Hensen B, Baggaley R, Wong VJ, Grabbe KL, Shaffer N, Lo YRJ, Hargreaves J. Universal voluntary HIV testing in antenatal care settings; a review of contribution of provider-initiated testing \& counselling. Tropical Medicine and International Health. 2012; 17 (1): 59-70.

10. Leon N, Matthews C, Lewin S, Osler M, Boulle A, Lombard C. A Comparison linkage to HIV care after provider-initiated HIV testing and counselling (PITC) versus voluntary counselling and testing (VCT) for patients with sexually transmitted infection in Cape Town, South Africa. BMC Health Service Research. 2014;14 (350): 1-12.

11. Rogers A, Meundi A, Amma A, Rao A, Shetty P, Antony J, et al. HIV- related knowledge, attitude, perceived benefits, and risk of HIV testing among pregnant women in rural Southern India. AIDS patient care and STDs. 2006; 20 (11): 803-11.

12. Paoli MM de, Manongi R, Klepp K. Factors influencing acceptability of voluntary counseling and HIV testing among pregnant women in Northern Tanzania. AIDS Care 2004; 16: 411-25.

13. Smolak A, Bassel NE. Multilevel stigma as barier to HIV testing in Central Asia: a contest-a context quantified. AIDS and Behaviour. 2013; 17 (8): 2742-55.

14. Baiden F, Remes R, Baiden R, Williams J, Hodgson A, Boelaert M, Buve A. Voluntary counseling and HIV testing for pregnant women in the Kassena-Nankana District of Northern Ghana: is couple counseling the way forward? AIDS care. 2005; 17(5): 648-57.

15. Ivers L, Freedberg K, Mukherjee J. Provider initiated HIV testing in rural Haiti: low rate of missed opportunities for diagnosis of HIV in a primary care clinic. AIDS Research and Therapy. 2007; 4: 28.

16. Salari P, Azizi M. The necessity of HIV testing in Iranian pregnant women and its ethical consideration. Journal of Medical Ethics and History. 2009; 2(1): 1-5.

17. Hardisman. HIV/AIDS di Indonesia: fenomena gunung es dan peranan pelayanan kesehatan primer. Kesmas: Jurnal Kesehatan Masyarakat Nasional. 2009; 3(5): 236-40. 